\title{
Molecular study on Pasteurella multocida and Mannheimia granulomatis from Kenyan Camels (Camelus dromedarius)
}

Ilona V. Gluecks ${ }^{1 \dagger}$, Astrid Bethe $^{2 \dagger}$, Mario Younan ${ }^{3+}$ and Christa Ewers ${ }^{4 *}$

\begin{abstract}
Background: Outbreaks of a Haemorrhagic Septicaemia (HS) like disease causing large mortalities in camels (Camelus dromedarius) in Asia and in Africa have been reported since 1890. Yet the aetiology of this condition remains elusive. This study is the first to apply state of the art molecular methods to shed light on the nasopharyngeal carrier state of Pasteurellaceae in camels. The study focused on HS causing Pasteurella multocida capsular types B and E. Other Pasteurellaceae, implicated in common respiratory infections of animals, were also investigated.

Methods: In 2007 and 2008, 388 nasopharyngeal swabs were collected at 12 locations in North Kenya from 246 clinically healthy camels in 81 herds that had been affected by HS-like disease. Swabs were used to cultivate bacteria on blood agar and to extract DNA for subsequent PCR analysis targeting P. multocida and Mannheimia-specific gene sequences.

Results: Forty-five samples were positive for $P$. multocida genes $\mathrm{kmt}$ and $\mathrm{ps} /$ and for the $P$. multocida Haemorrhagic Septicaemia (HS) specific sequences KTSP61/KTT72 but lacked HS-associated capsular type B and E genes capB and capE. This indicates circulation of HS strains in camels that lack established capsular types. Sequence analysis of the partial 16S rRNA gene identified 17 nasal swab isolates as 99\% identical with Mannheimia granulomatis, demonstrating a hitherto unrecognised active carrier state for M. granulomatis or a closely related Mannheimia sp. in camels.

Conclusions: The findings of this study provide evidence for the presence of acapsular $P$. multocida or of hitherto unknown capsular types of P. multocida in camels, closely related to P. multocida strains causing HS in bovines. Further isolations and molecular studies of camelid P. multocida from healthy carriers and from HS-like disease in camels are necessary to provide conclusive answers. This paper is the first report on the isolation of M. granulomatis or a closely related new Mannheimia species from camelids.
\end{abstract}

Keywords: Pasteurellaceae, Pasteurella multocida, Mannheimia, Camels, Camelus dromedarius, Haemorrhagic Septicaemia

\section{Background}

Pasteurella multocida capsular types B and E are the specific cause of seasonal outbreaks of Haemorrhagic Septicaemia (HS) in tropical cattle and buffaloes [1-3]. The veterinary literature provides a long record of an HS-like disease causing significant mortality in camels [4-8]. Yet the aetiology of HS in camels remains elusive $[1,3,9]$. Previous reports on HS-like disease in camels

\footnotetext{
* Correspondence: Christa.Ewers@vetmed.uni-giessen.de

${ }^{\dagger}$ Equal contributors

${ }^{4}$ Institute of Hygiene and Infectious Diseases of Animals, Justus-Liebig

University Giessen, Giessen, Germany

Full list of author information is available at the end of the article
}

often failed to isolate the pathogen or provided only limited information on phenotypical characteristics of the isolates [9]. Attempts to infect camels with highly virulent Pasteurella multocida capsular type B strains produced only very mild clinical symptoms that resolved completely within 3 days [9].

A respiratory disease in Ethiopian camels caused by Pasteurella (Mannheimia) haemolytica has been described by Bekele [10]. This pilot study is the first of its' kind to use state of the art molecular methods for investigating Pasteurellaceae in camels. 


\section{Methods}

In 2007 and 2008, 388 nasopharyngeal swabs were collected at 12 locations in North Kenya from 246 clinically healthy camels in 81 herds that had reportedly been affected by outbreaks of HS-like disease. Flocculated swabs (FLOQSwabs ${ }^{\oplus}$ ) were used for DNA extraction while swabs in Amies transport medium (Sterilin ${ }^{\odot}$ ) were used for standard bacteriological investigation. Bacteriological examination and extraction of DNA was carried out at a laboratory in Nairobi (Analabs Ltd.). DNA eluates from 341 swabs and 19 isolated Pasteurella-like cultures were transferred to the Institute for Microbiology and Epizootics at Freie Universität Berlin (IMT/ FUB) in Germany. At the IMT/FUB, DNA was extracted from 19 culture isolates, two of which did not belong to the Pasteurellaceae based on PCR results. Seventeen isolates were subsequently selected for biochemical testing to differentiate M. granulomatis from other Mannheimia spp. according to Ewers et al. (2004) [11]. Three hundred five samples with positive reaction in the $16 \mathrm{~S}$ rRNA gene PCR, as well as, heat denatured DNA from bacterial cultures were investigated for the presence of $P$. multocida- and $M$. haemolytica- specific DNA sequences. For P. multocida the specific sequences tested were $k m t$, psl, and KTSP61/KTT72. Samples that proofed positive in one of these PCRs were further tested for capsular genes $c a p A, c a p B, c a p D, c a p E$, and $c a p F$, and for virulenceassociated genes tox $A, p t f A, p f h A$ oma87, ompH, hgbA, $h g b B, \operatorname{exbB/tonB}, \operatorname{tbp} A$, nanB, and nanH. To detect pathogenic Mannheimia spp., we screened for the leukotoxin $(l k t A)$ and the outer membrane protein (pomA) genes. All PCRs, except for the $P$. multocida capsular gene PCR, which was performed as a multiplex PCR, were conducted as single PCRs according to previously published protocols [12-18].

\section{Results}

The species $P$. multocida could not be isolated from 312 nasal swabs cultured on Blood Agar. Of the 305 DNA eluates containing sufficient quantities of DNA to undergo molecular characterization, 60 were positive for at least one of the $P$. multocida species-specific sequences tested by PCR. Forty-five samples gave a positive result for the HS- associated sequence KTSP61/ KTT72, known to be present in P. multocida capsular type B strains. Neither $c a p B$ nor $c a p E$ gene, encoding HS-associated capsular types B and E, were detected in the sample material. Blast search of $18 \mathrm{KTSP} 61 / \mathrm{KTT} 72$ sequences [19] matched with high scores (98.8-99\%) to nucleotide sequences submitted under GenBank accession numbers AF016260 (P. multocida unknown protein 1 gene, partial cds and unknown protein 2 gene, complete cds), AY948545.1 (P. multocida HS-B specific genomic sequence) and AJ421513.1 (P. multocida DNA fragment specific for HS). CapA and capD genes encoding for $P$. multocida capsular types $\mathrm{A}$ and $\mathrm{D}$ were identified in five and in one sample, respectively. Screening for adhesionrelated genes $p t f A$ and $p f h A$ was positive in 15 and 2 samples, respectively. Outer membrane protein gene ompH was detected in 10, oma87 in 14 samples. While tox $A$, encoding the dermonecrotoxin, was not found in any sample, iron acquisition-related genes were present as follows: $h g b A(n=12), h g b B(n=11), \operatorname{exbB/tonB}(n=1)$. Neuraminidase encoding genes $n a n B$ and $n a n H$ were present in 9 and 11 samples, respectively.

The biochemical profiles of the 17 Mannheimia spp. isolates characterised phenotypically were inconsistent and differed from the biochemical profile described for $M$. granulomatis [20], namely Sorbitol: pos.; $\alpha$-Fucosidase: neg.; $\beta$-Galactosidase: variable. Of the 305 eluates tested, none was positive for Mannheimia spp. associated sequences $l k t A$ or pomA. According to the $16 \mathrm{~S}$ rRNA sequence analysis performed on 19 cultures from the nasopharynx of healthy camels, 17 sequences showed closest relatedness (98-99\%) to sequences from M. granulomatis, previously classified as $P$. granulomatis, Bisgaard taxon 20 and P. haemolytica biogroup $3 \mathrm{~J}[21,22]$.

\section{Discussion}

This study investigated the active (nasopharyngeal) carrier state for Pasteurellaceae in Kenyan camels. Importance of the latent carrier state in the epidemiology of Pasteurellosis was reiterated by Dziva et al. (2008) [23].

The fact that no P. multocida capsular type B or $\mathrm{E}$ specific DNA sequences were identified in this study may indicate the presence of non-capsulated strains or the emergence of a hitherto unknown capsular type of $P$. multocida in camels. According to the OIE Terrestrial Manual [24] vaccines against Haemorrhagic Septicaemia in cattle and buffaloes must be based on local isolates that represent the prevalent serotype; seed cultures for the production of HS vaccines should contain capsulated organisms. Based on the results of this study the indiscriminate use of vaccines based on HS causing $P$. multocida isolates from cattle and buffaloes cannot be recommended for the prevention of HS-like disease in camels. - This is the first molecular study to confirm the presence of $P$. $m u l$ tocida capsular types A and D specific DNA sequences in the nasopharynx of healthy Kenyan carrier camels, albeit at low frequency. Both capsular types have been reported in camels previously [25] based on phenotypic characterisation. Failure to culture $P$. multocida in this study is possibly related to the fastidiousness of the species which does not withstand cold chain transport of several days [26].

The $l k t A$ or pomA sequences do not occur regularly in all Mannheimia species or strains [27, 28], hence negative findings do not rule out presence of Mannheimia spp., but $l k t A$-negative $M$. haemolytica strains are reported to 
be less virulent. In this study the most common Pasteurellaceae species cultured from the nasopharynx of healthy carrier camels in North Kenya and identified by 16S rRNA sequence analysis was a Mannheimia sp. with $98 \%$ to $99 \%$ sequence identity to $M$. granulomatis. Only more recently has $M$. granulomatis been recognised as a significant pathogen in domestic and wild ruminants [29-31]. Phenotypic characterization of Pasteurellaceae species is of limited value [32] and published phenotypic characteristics for $M$. granulomatis are based on a limited number of bovine, leprine and deer strains $[2,21,22,30]$. Hence it is to be expected that biochemical reactions of Kenyan camelid M. granulomatis strains differ from those described for M. granulomatis under http://www.bacterio.net/mannhei mia.html/. Comparison of our results with a previous communication on involvement of $P$. (M.) haemolytica in respiratory disease in Ethiopian camels [10] is also limited, because the methodology used there would not have permitted a differentiation between $M$. granulomatis, $M$. (Pasteurella) haemolytica and other Mannheima spp. The possibility that this respiratory pathogen isolated from Ethiopian camels [10] may in fact have been M. granulomatis or a new Mannheimia species very closely related to $M$. granulomatis cannot entirely be ruled out.

\section{Conclusions}

This study has documented the carrier state for acapsular $P$. multocida or unknown capsular types of $P$. multocida, closely related to the $P$. multocida strains causing HS in cattle and buffaloes, in healthy camels. At the same time the study found no evidence for the presence of P. multocida capsular types B and $\mathrm{E}$ or their specific DNA sequences in healthy camels in North Kenya. Further isolations and molecular studies of camelid $P$. multocida from healthy carriers and from HS-like disease in camels are necessary to provide conclusive answers. To our best knowledge this is the first report on the isolation of $M$. granulomatis or a closely related new Mannheimia species from camelids.

\section{Abbreviations \\ DNA: Deoxyribonucleic acid; HS: Haemorrhagic Septicaemia; IMT/ FUB: Institute for Microbiology and Epizootics at Freie Universität Berlin; PCR: Polymerase Chain Reaction; RNA: Ribonucleic acid; rRNA: Ribosomal ribonucleic acid}

\section{Acknowledgements}

We would like to thank Ines Diehl for excellent technical assistance.

\section{Funding}

This work was supported by the Wellcome Trust (Grant number 081073/Z/06/Z).

\section{Availability of data and materials}

All data are available in the main text of the manuscript. Materials are available at the Institute of Microbiology and Epizootics, Centre for Infection Medicine, Free University Berlin, Germany.

\section{Authors' contributions}

All authors conceived and planned the study. IG and MY performed the sampling, DNA extraction, primary cultures and organized the transfer of samples to Germany. AB and CE designed the laboratory and molecular experiments. All authors contributed on the draft of the manuscript. All authors read and approved the final manuscript.

\section{Ethics approval}

All animal samples were taken for the purpose of diagnostic of bacterial infectious agents. Informed consent was obtained from the camel owners.

\section{Competing interests}

The authors declare that they have no competing interests.

\section{Publisher's Note}

Springer Nature remains neutral with regard to jurisdictional claims in published maps and institutional affiliations.

\section{Author details}

'Vétérinaires sans Frontières Suisse, Nairobi, Kenya. ${ }^{2}$ Institute of Microbiology and Epizootics, Centre for Infection Medicine, Free University Berlin, Berlin, Germany. ${ }^{3}$ Vétérinaires sans Frontières Germany, Nairobi, Kenya. ${ }^{4}$ Institute of Hygiene and Infectious Diseases of Animals, Justus-Liebig University Giessen, Giessen, Germany.

Received: 23 June 2016 Accepted: 11 August 2017

Published online: 22 August 2017

\section{References}

1. Bain RVS, De Alwis MCL, Carter GR, Gupta BK. Haemorrhagic Septicaemia. Rome: FAO Animal Production and Health Paper 33; 1982. p. 54.

2. Songer JG, Post KW. The Genera Mannheimia and Pasteurella. In: Songer JG, Post KW, editors. Veterinary Microbiology, Bacterial and Fungal Agents of Animal Disease, Chapter 23. USA: Elsevier Inc; 2005. p. 434.

3. Office International Epizootics (OIE). Report of the $2^{\text {nd }}$ Meeting of the OIE ad hoc Group on Disease of Camelids. Paris, 3-5 May 2010.

4. Steel JH. A Manual of the Diseases of the Camel and of his Management and Uses. Madras: Indian Veterinary Manuals III, The Lawrence Asylum Press (printed by GW Taylor); 1890. p. 54-5.

5. Leese AS. The Camel - a treatise on the one-humped camel in health and disease. Stanford, Lincolnshire, UK: Haynes \& Son; 1927. p. 270-2.

6. Masia R. Les maladies microbiennes du dromadaire et leur importance en Afrique du Nord. Thése pour le Doctorat Vétérinaire, L'École Nationale Vétérinaire d'Alfort, Imprimerie R.Foulon, Paris; 1953. p. 33-34.

7. McGrane JJ, Higgins A. (1986) Infectious Diseases of the Camel, Viruses Bacteria and Fungi, Pasteurellosis. In: Higgins A, editor. . Baillière Tindall: The Camel in Health and Disease; 1986. p. 103.

8. Schwartz HJ, Dioli M. The one-humped camel in Eastern Africa - A pictorial guide to disease, health care and management. Berlin, Germany: Verlag Josef Margraf; 1992

9. Wernery U, Kinne J, Schuster RK. 1.1.8 Pasteurellosis. In: Camelid Infectious Disorders. Paris, France: World Organisation for Animal Health OIE; 2014. p. 58-65.

10. Bekele T. Studies on the respiratory disease 'sonbobe' in camels in the eastern lowlands of Ethiopia. Trop Anim Health Prod. 1999;31 (6):333-45.

11. Ewers C, Lübke-Becker A, Wieler LH. Mannheimia haemolytica and the pathogenesis of pneumonic pasteurellosis. Berl Munch Tierarzt Wochenschr. 2004;3-4:97-115.

12. Doughty SW, Ruffolo CG, Adler B. The type 4 fimbrial subunit gene of Pasteurella multocida. Vet Microbiol. 2000;72:79-90.

13. Ewers C, Luebke-Becker A, Bethe A, Kiessling S, Filter M, Wieler LH. Virulence genotype of Pasteurella multocida strains isolated from different hosts with various disease status. Vet Microbiol. 2006;114:304-17.

14. Kasten RW, Hansen LM, Hinojoza J, Bieber D, Ruehl WW, Hirsh D. Pasteurella multocida produces a protein with homology to the $\mathrm{P} 6$ outer membrane protein of Haemophilus influenzae. Infect Immun. 1995;63:989-93.

15. Townsend KM, Frost AJ, Lee CW, Papadimitriou JM, Dawkins HJ. Development of PCR assays for species- and type-specific identification of Pasteurella multocida isolates. J Clin Microbiol. 1998;36:1096-100. 
16. Townsend KM, Hanh TX, O'Boyle D, Wilkie I, Phan TT, Wijewardana TG, Trung NT, Frost AJ. PCR detection and analysis of Pasteurella multocida from the tonsils of slaughtered pigs in Vietnam. Vet Microbiol. 2000;72:69-78.

17. Guenther S, Schierack P, Grobbel M, Lubke-Becker A, Wieler LH, Ewers C. Real-time PCR assay for the detection of species of the genus Mannheimia. J Microbiol Methods. 2008;75:75-80

18. Townsend KM, Boyce JD, Chung JY, Frost AJ, Adler B. Genetic organization of Pasteurella multocida cap Loci and development of a multiplex capsular PCR typing system. J Clin Microbiol. 2001;39:924.929.

19. http://blast.ncbi.nlm.nih.gov/Blast.cgi (Accessed on $18^{\text {th }}$ March, 2017).

20. http://www.bacterio.cict.fr (Accessed on $18^{\text {th }}$ March, 2017).

21. Angen O, Mutters R, Caugant DA, Olsen JE, Bisgaard M. Taxonomic relationships of the [Pasteurella] haemolytica complex as evaluated by DNADNA hybridizations and 165 rRNA sequencing with proposal of Mannheimia haemolytica gen. nov., comb. nov., Mannheimia granulomatis comb. nov. Mannheimia glucosida sp. nov., Mannheimia ruminalis sp. nov. and Mannheimia varigena sp. nov. Int J Syst Bacteriol. 1999;49:67-86.

22. Angen O, Quirie M, Donachie W, Bisgaard M. Investigations on the species specificity of Mannheimia (Pasteurella) haemolytica serotyping. Vet Microbiol. 1999:65:283-90.

23. Dziva F, Muhairwa AP, Bisgaard M, Christensen H. Diagnostic and typing options for investigating diseases associated with Pasteurella multocida. Vet Microbiol. 2008;128(1-2):1-22.

24. World Organisation for Animal Health - WOAH/OIE. Manual of Diagnostic Tests and Vaccines for Terrestrial Animals (mammals, birds and bees). 2012; $7^{\text {th }}$ edition, Volume 1, Chapter 2.4.12. - Haemorrhagic septicaemia, 732-744.

25. Seleim RS, Amal RT, Sahar RM, Nada H, Gobran RA. ELISA and other tests in the diagnosis of Pasteurella multocida infection in camels. Presented at Deutscher Tropentag, International Research on Food Security, Natural Resource Management and Rural Development Georg-August-Universität Göttingen, October 8-10 2003; posted on 'health \& life sciences' May 2003 http://www.priory.com/vet/camel.htm.

26. Younan M. Biochemical characterization and identification of capsular antigen of ovine Pasteurella strains of different geographical provenance (Syria / South Germany) and of a collection of bovine Pasteurella haemolytica isolates. Veterinary Faculty - Free University Berlin, 1988.

27. Omaleki L, Browning GF, Barber SR, Allen JL, Srikumaran S, Markham PF. Sequence diversity, cytotoxicity and antigenic similarities of the leukotoxin of isolates of Mannheimia species from mastitis in domestic sheep. Vet Microbiol. 2014;174(1-2):172-9.

28. Shanthalingam S, Goldy A, Bavananthasivam J, Subramaniam R, Batra SA Kugadas A, Raghavan B, Dassanayake RP, Jennings-Gaines JE, Killion HJ, Edwards WH, Ramsey JM, Anderson NJ, Wolff PL, Mansfield K, Bruning D, Srikumaran S. PCR assay detects Mannheimia haemolytica in culturenegative pneumonic lung tissues of bighorn sheep (Ovis canadensis) from outbreaks in the western USA, 2009-2010. J Wildl Dis. 2014;50(1):1-10.

29. Riet-Correa F, Ladeira SL, Andrade GB, Carter GR. Lechiguana (focal proliferative fibrogranulomatous panniculitis) in cattle. Vet Res Comm. 2000;24(8):557-72.

30. Blackall PJ, Bisgaard M, Stephens CP. Phenotypic characterisation of Australian sheep and cattle isolates of Mannheimia haemolytica, Mannheimia granulomatis and Mannheimia varigena. Australian Vet J. 2002;80(1-2):87-91.

31. Bojesen AM. Larsen J, Pedersen AG, M"orner T, Mattson R \& Bisgaard M. Identification of a novel Mannheimia granulomatis lineage from lesions in roe deer (Capreolus capreolus). J Wildl Dis. 2007;43:345-52.

32. Koendgen $\mathrm{S}$, Leider $\mathrm{M}$, Lankester $\mathrm{F}$, Bethe $\mathrm{A}$, Lubke-Becker $\mathrm{A}$, Fabian $\mathrm{H}$ Leendertz EC. Pasteurella multocida Involved in Respiratory Disease of Wild Chimpanzees. PLoS One. 2011;6(9):e24236.

\section{Submit your next manuscript to BioMed Central and we will help you at every step:}

- We accept pre-submission inquiries

- Our selector tool helps you to find the most relevant journal

- We provide round the clock customer support

- Convenient online submission

- Thorough peer review

- Inclusion in PubMed and all major indexing services

- Maximum visibility for your research

Submit your manuscript at www.biomedcentral.com/submit
Biomed Central 